\title{
The New Global Agenda and the Future of the Multilateral Development Bank System
}

\author{
A. Bhattacharya, H. Kharas, M. Plant, A. Prizzon
}

Amar Bhattacharya - Senior fellow, Global Economy and Development program, The Brookings Institution; USA, Washington, DC 20036, 1775 Massachusetts Ave., NW; E-mail: communications@brookings.edu

Homi Kharas - The interim vice president and director of Global Economy and Development program, The Brookings Institution; USA, Washington, DC 20036, 1775 Massachusetts Ave., NW; E-mail: hkharas@ brookings.edu

Mark Plant - The director of development finance and senior policy fellow, Center for Global Development; USA, Washington DC 20036, 2055 L Street NW; E-mail: mplant@cgdev.org

Annalisa Prizzon - Senior research fellow, Overseas Development Institute; UK, London SE1 8NJ, 203 Blackfriars Road; E-mail: a.prizzon@odi.org.uk

"The New Global Agenda and the Future of the Multilateral Development Bank System" by Bhattacharya A., Kharas H., Plant M., Prizzon A., English text. The Brookings Institution (Brookings), Overseas Development Institute (ODI), the Center for Global Development (CGD) ${ }^{1}$

(C) Brookings, ODI \& CGD. Translated and reproduced with permission. Brookings, ODI \& CGD are not responsible for the accuracy of this translation.

${ }^{1}$ Bhattacharya A., Kharas H., Plant M., Prizzon A. (2018) The New Global Agenda and the Future of the Multilateral Development Bank System. The Brookings Institution, Overseas Development Institute (ODI), the Center for Global Development (CGD), February 2018. Available at: https://www.brookings.edu/ wp-content/uploads/2018/02/epg_paper_on_future_of_mdb_system_jan301.pdf.

The Brookings Institution is a nonprofit organization devoted to independent research and policy solutions. Its mission is to conduct high-quality, independent research and, based on that research, to provide innovative, practical recommendations for policymakers and the public.

The Overseas Development Institute (ODI) is a leading independent think tank on international development and humanitarian issues. Its mission is to inspire and inform policy and practice which lead to the reduction of poverty and the achievement of sustainable livelihoods in developing countries by locking together high quality applied research, practical policy advice, and policy-focused dissemination and debate. The Center for Global Development works to reduce global poverty and inequality through rigorous research and active engagement with the policy community to make the world a more prosperous, just, and safe place for us all.

The conclusions and recommendations of this publication are solely those of its authors, and do not reflect the views of the Institutions, their management, or their other scholars.

Support for this publication was generously provided by the Bill \& Melinda Gates Foundation and The Rockefeller Foundation. Brookings, CGD, and ODI recognize that the value they provide is in the absolute commitment to quality, independence, and impact. Activities supported by their donors reflect this commitment.

An earlier version of this paper was presented at the G-20 Eminent Persons Group Symposium on Global Financial Governance in Frankfurt, Germany, on December 4, 2017. This version of the paper has greatly benefited from the discussion. 
Abstract

The new global agenda, with Agenda 2030 at its core, is ambitious, comprehensive, and universal. The three central goals now are to reignite growth, deliver on the sustainable development goals (SDGs), and meet the ambitions of the Paris climate agreement aimed at mitigating climate change and adapting to its effects. Achieving these goals will require a significant scaling up and reorientation of investments, especially for sustainable infrastructure and human development. Implementing this agenda is urgent, as the world is witnessing the largest wave of urban expansion in history and more infrastructure will come on stream over the next 15 years than the world's existing stock. This is also the last opportunity to manage remaining significant demographic transitions.

The capital investments and technological choices made in the coming two decades will lock-in carbonization, urbanization, and demographic trends that will determine the future of humanity and our planet for the rest of the century and beyond.

The backdrop for achieving these ambitions is challenging. In many countries, investment and productivity growth have decelerated, there is growing inequality and persistent unemployment, fragility and tensions are rising, and the incidence and vulnerability to shocks has grown. At the same time, major opportunities exist to tap the potential of new technologies and the growing capacity of the private sector. Today's hyper-connected world requires a mix of activities spanning private goods, national public goods, and regional/global public goods to meet the challenges of sustainable development.

The agenda requires government intervention to reach adequate scale, to take social and environmental sustainability seriously, and to manage spillovers across sectors and borders. It also requires stepped up international cooperation to drive transformative change and mobilize financing on an unprecedented scale.

With their highly effective capacity to help countries strengthen policy and institutional foundations and to leverage finance, multilateral development banks (MDBs) have a central role to play. They are trying to respond, but human and financial constraints and unclear and expanded mandates from shareholders are holding them back. Clarifying their mandates and addressing the constraints are essential to enable them to scale up and make more effective their support for the new global agenda.

The unique financial structure of the MDBs allows them to leverage contributions from MDB shareholders and multiply them into financing at low cost. This financial capacity can in turn further crowd-in other sources of finance, especially from the private sector. With better system-wide coordination, MDBs can scale up their impact to deliver for increasingly differentiated clients, but this requires shareholder consensus on, and financial support for, expanded efforts.

Independent evaluations suggest that each MDB is individually performing well, but the system as a whole is not delivering enough.

This paper suggests ways to improve policy and operational coherence among MDBs and outlines how better shareholder governance could bring this about. It focuses on the need for stepped-up financing of investments in developing countries, but should be viewed in the broader context of managing globalization, especially with regard to trade and financial stability.

Key words: multilateral development banks; sustainable development goals; investments; human development; global governance

For citation: Bhattacharya A., Kharas H., Plant M., Prizzon A. (2018) The New Global Agenda and the Future of the Multilateral Development Bank System. International Organisations Research Journal, vol. 13, no 2, pp. 101-124 (in Russian and English). DOI: 10.17323/1996-7845-2018-02-06.

\section{MDB Coordination to Act as a System}

Subject matter specialization among MDBs has evolved in ways that can be applied not just regionally, but also globally. More robust mechanisms to share best practice and allow sister institutions to share expertise will permit economies of scale and scope in providing services. The opportunities for enhanced collaboration extend to all sectors and to areas of global collective 
action where the MDBs have comparative advantage. Infrastructure, because of its size, offers particular opportunities for collaboration.

Areas for stepped-up collaboration include: (a) joint efforts on diagnostic work and improving data; (b) platforms for project preparation and application of common standards and benchmarks including for sustainable infrastructure; (c) knowledge platforms and tools for strengthening policy and institutional foundations and provision of technical assistance; and (d) cooperation on establishment of financing structures that can unlock investments at scale.

MDBs should also review how competition between them in policy conditionality, pricing, and financing modalities affects the impact of system-wide support to each country. Competition can be healthy and offer recipient countries with a broader range of options, but it needs to take place in the context of a healthy eco-system and a level playing field.

\section{Support to All Clients and Global Cooperation in an Interconnected World}

For MDB engagement to add value across all income groups and drive the frontiers of growth and development where financial markets are imperfect and where knowledge and capacity gaps exist, the concept of "graduation" based on per capita income needs to be adjusted. A more adaptive framework would determine MDB engagement based not just on income level, but on the development impact in the particular country and sector, and on the value the engagement brings to the system as a whole. From a development finance perspective, the role of direct financial support will diminish as client countries gain better access to financial markets, and the mobilization of other sources of finance, especially from the private sector, will become more important. Yet the progression away from needing direct MDB support happens in fits and starts and both policy and capital market failures suggest that MDB finance can play an important role in the social sectors, infrastructure and in the response to shocks across all income groups.

While the MDBs can enhance their support everywhere, the system is falling short with respect to three types of clients: fragile and conflict affected states, highly indebted countries, and upper middle-income countries (UMICs).

Fragile and conflict/violence affected states (FCVs): MDBs should deepen their support for institutional development in FCV affected countries, rigorously evaluating pilot approaches and scaling up what works. Areas such as public administration reform, public utility management, and oversight of the security sector are ripe for new, innovative approaches by the MDBs and their partners. Greater flexibility in approaches and longer timeframes are needed in FCV countries, and MDBs shareholders need to adjust oversight to these conditions.

High-debt countries: We would recommend MDBs jointly prioritize and strengthen debt management capacity in borrowing countries. They should also review how the quality of public investment, the track records of policy reforms, and availability and use of policy space affect debt sustainability assessments. They should develop principles and procedures for debt restructuring that reflect the increasingly complex nature of the creditor community.

Upper middle-income countries: We believe that there is a powerful argument for the MDB system to engage in all developing countries, including UMICs. The real discussion for shareholders should be on the criteria for engagement, and the need to demonstrate a clear developmental purpose for any intervention (often sub-national or public good for UMICs). The "cascade" principles provide a useful frame: test whether there is a real need for public financing (including as a contribution to a global externality); identify whether such needs could be 
obviated in future through policy and institutional strengthening, but engage where a compelling development case can be made.

\section{The Provision of Global Public Goods}

In addition to their financial role, the MDBs are well positioned to contribute to global challenges and spillovers too - from climate to pandemics to migration to digitization and the future of work to coping with shocks to peace and security. The primary comparative advantage of MDBs when engaging around these global public goods (GPGs) and bads comes from their country engagement, but they can also contribute to platforms for global agreement and action with other partners, especially the U.N. At present, the assignment of responsibilities is ad hoc across the multilateral system, with clear objectives and accountabilities often lacking.

\section{Using Balance Sheets to Leverage Resources}

There have been many recommendations on MDB capital adequacy, the impact of callable capital, balance sheet optimization, credit risk concentration and pooling, and the like. We suggest that the deeper issue is to agree on, and signal, the scale of activity of MDBs (both financial and non-financial service delivery) and to work backward to develop scenarios for capital and risk tolerance.

In our view, scaling the system to deliver trillions more in project and program finance through direct and catalytic finance over the next decade or so is an appropriate starting point for shareholder discussions. Our calculations suggest this is quite feasible, given considerable leverage and mobilization opportunities, but needs political will (and perhaps changes in credit rating methodologies). Such scaling will also require a pivot in emphasis from direct financing to mobilization, with attendant implications for internal incentives, instruments, and the business model.

MDBs could also develop financing "exit mechanisms" to turn over their capital more rapidly for greater development impact. In such schemes, private sector investors with an appetite for developing country investments could purchase mature financial assets from MDBs, freeing their capital. While MDBs already have asset sales programs, getting such mechanisms to function at scale would require a significant change in pricing and business models.

\section{Systemic Governance Issues}

Shareholder misalignment and outdated governance are at the heart of many of the MDBs' limitations. The effectiveness and legitimacy of the MDB system requires a shared vision and purpose across stakeholders. Having an MDB system that is fit for purpose requires new governance arrangements that preserve the multilateral character of the institutions in a changing world. This applies to the processes of leadership selection and to the rules by which shareholders make decisions. Reforms to corporate governance structures to ensure alignment of incentives and accountabilities would allow MDB staff and management to be more cost-effective and responsive to the technocratic needs of clients.

Shareholders need to set expectations for what the multilateral development system should deliver as contributions toward Agenda 2030, including how they help mitigate shocks and provide global public goods. Given the urgency for action in the upcoming two decades, shareholders also urgently need to assess whether progress on outcomes is rapid enough. Performance 
of the system can in turn be assessed against these expectations, with periodic adjustments to ambitions and mandates as new challenges emerge.

A governance framework that periodically takes stock of system-wide results, say every five years, would facilitate follow-up and course corrections in individual institutions. A careful system-wide review of the costs and benefits of current Board structures and staffing is needed.

Strategy setting for the long-term and accountability for results are urgently needed for the MDB system as a whole. The MDBs have made a start in thinking through collective commitments (see the Joint MDB Statement of Ambitions for Crowding in Private Finance).

Examining the distribution of specializations across the multilateral system requires reckoning with the significant presence of U.N. agencies in many domains. Indeed, MDB shareholders need to be wary of the propagation of competing mandates that could undercut or duplicate other international efforts to achieve the SDGs.

\section{The New Global Agenda and the Future of the MDB System}

\section{Section 1. The Changed Global Context}

\section{A New Global Agenda and the Criticality of the Coming Decades}

Agenda 2030, agreed to by 193 countries in 2015, is more comprehensive in scope, universal in its relevance to countries across the income spectrum, and more ambitious in its targets than the Millennium Development Goals (MDG) agenda of 2000-2015. The central goals now are to reignite growth, to deliver on the SDGs, to ramp up actions in line with the ambitions of the Paris climate agreement; to mitigate vulnerabilities and shocks; and to facilitate collective action to tackle cross-border issues such as pandemics and financial and debt crises.

The backdrop for achieving these ambitious objectives is challenging, as investment and productivity have decelerated in advanced and developing economies, and the world economy is facing major structural changes - including growing multipolarity, climate change, urbanization, demographic transitions and the uncertain labor market effects of technological change.

On the one hand, if protracted crises in fragile situations are resolved, over the next few decades, policymakers could help eliminate extreme poverty and advance sustainable development. On the other, populations everywhere face structural forces that could affect development for decades to come.

The largest wave of urban expansion in history is happening now - urban populations will double in a generation and the shape of urban expansion will dictate our patterns of production and consumption for generations.

During the next 15 years, we will be adding more infrastructure than the existing stock. The quality of this infrastructure will determine the path of carbon emissions and climate change. We can make the new infrastructure and urban areas sustainable and attractive or lock cities into a future where we cannot move or breathe. Under such a dystopian outlook, global temperatures would rise by more than 2 degrees Celsius, and bring with it a slew of consequential impacts and risks.

The next two decades are also the last opportunity to address the demographic transitions occurring in the developing world, especially in Africa, where a demographic youth bulge could either contribute to more jobs and prosperity, or fuel frustration and anger and a scramble to migrate. Related to this, girls' secondary education over the next 15 years will drive fertility and be the difference between a global population of 9 billion or 11 billion by the end of the century. 


\section{Value Proposition of the MDBs}

The value proposition for the multilateral development system rests on the MDBs' ability to be trusted partners who can provide scaled-up and least-cost services, using a strong country presence, which allows them to tailor solutions to client needs. ${ }^{2}$ It is built on an understanding among shareholders that multilateral solutions can complement bilateral approaches by pooling resources, avoiding waste and duplication, and building a critical mass of specialized skills.

From the clients' perspective, the value proposition of the multilateral development institutions comes from the experiences and practices gained from 70 years of development cooperation. ${ }^{3}$ MDBs provide:

- A sustainable development lens that supports policy and institutional reforms and capacity building, enhances the quality of projects and programs, and lays the basis for scaling up or transformative change, or helps build resilience and capacity to rapidly respond to, or avoid, shocks.

- A stable transfer of long-term resources at low cost (relative to alternative market access for the borrower), the mobilization of financing from other sources, especially from the private sector, and an ability to address impediments and de- risk programs and projects. Financial transfers can be particularly helpful during episodes of external crisis. ${ }^{4}$

- A global/regional approach to help tackle spillovers, most importantly in the areas of climate action, disease surveillance and treatment, conflict prevention, migration, and economic stabilization, where "bads" from one country can seriously affect others or where there are opportunities for positive spillovers such as regional connectivity and growth poles. ${ }^{5}$

In sum, multilaterals offer a unique combination of benefits. They provide large-volume finance at the most attractive terms combined with knowledge, policy advice, institutional strengthening, and technical assistance for projects, with a regional or global outlook.

The global development challenges of the world today - where issues are interconnected, externalities are prevalent, non-market social concerns must be factored in, and scale and speed of implementation are urgent - require far more than private sector investment. They require public involvement, and governments in all developing countries look to MDBs for support.

Most commonly, such support comes from individual MDBs through project-based activities. Each multilateral agency has tended to operate individually, and each has developed specialized skills and knowledge that are partly geographic and partly thematic. Too often, such approaches are inimical to system-wide approaches.

There are good reasons for the MDBs to work together as a system to increase the value added for their clients. These include getting to scale, reducing transaction costs and duplications, reinforcing impact through greater coherence, and optimizing use of the financial and human capital assets of each institution. System approaches that establish goals and targets, platforms for financing, common standards, and strong feedback loops can be useful to deal with the range of uncertainties in the world today and to spread successful innovations more

\footnotetext{
${ }^{2}$ In this submission, we primarily consider the experiences of the World Bank Group, AfDB, AsDB, EBRD and IADB, but the MDB system also includes the IsDB, NDB, AIIB, EIB and IFC.

${ }^{3}$ Of course, some countries have also raised concerns about low disbursement speeds, intrusive policy conditionality, and parallel operations that do not avail of country systems.

${ }^{4}$ The core MDB financial model is extremely powerful in channeling private investment into development projects. For example, with a total share capital investment of only $\$ 15.8$ billion since 1944 , the IBRD has supplied nearly $\$ 700$ billion in development financing [Humphrey, 2017].

${ }^{5}$ See for example [Ahluwalia et al., 2016], where the authors recommend creation of global public goods "windows" at the MDBs with funds that could be used to reduce the cost to borrowers of projects with positive regional or global spillovers.
} 
rapidly across countries. A systems approach would take into account the shifting requirements for development finance and the growing differentiation of clients. It would require greater policy and operational coherence among MDBs and stronger shareholder alignment.

\section{Toward a More Effective Development Finance System}

Although the original mission of MDBs was to transfer financial resources to developing economies, in most countries, this is no longer their principal function. Instead, MDBs are providers of development solutions. This often requires financing, as part of an effort to overcome imperfect capital markets, but with funding limited to what is necessary to ensure that solutions are adequately resourced. In the case of most middle-income countries (MICs), financial transfers from MDBs are small as a percent of total investments or total cross-border capital inflows.

If transferring financial resources to developing countries is the goal, MDBs must not crowd out private finance. However, when ambitious development outcomes are the goal, it becomes necessary to ensure that MDBs crowd-in private finance. Increasingly, mobilizing development finance also means developing and tapping into long-term local currency financial markets.

Capital markets in developing countries remain incomplete and unable to properly tackle the risks and high transaction costs associated with large-scale infrastructure, small- scale agriculture, social and environmental services with non-market spillovers, sub - national finance, or emergency finance. MDBs can often add value in these areas.

Since the 1980s, developing countries have become richer (and their own resources more plentiful), and private external finance has expanded in all countries. MDB concessional financing has risen, while the number of low-income countries (LICs) has shrunk to just 31 today. However, MDBs have become less important as a source of finance in most MIC countries ( 0.3 percent of GDP in lower middle-income countries (LMICs) and negligible in uppermiddle income countries (UMICs)).

Since 2000, LMICs have gotten most (two-thirds to four-fifths) of their foreign financing from foreign direct investment (FDI) and non-guaranteed private flows. Even LICs get onethird of their financing from these sources. The multilateral system is declining in relative size, although MDB flows are far less volatile than are private flows.

The World Bank Group (WBG) used to be the largest financial institution in all regions, but now, except in Africa, net disbursements from the Bank Group are lower than the net disbursements of the regional MDBs in their respective geographic focal areas.

Compositionally, the RDBs have grown to be commensurate in size and skills in relation to the regional departments of the WBG. With growing overlap in membership, a restrictive geographic-based architecture is giving way to a system where expertise can be deployed across the world.

\section{Understanding Changing Client Needs}

Clients have traditionally turned to international financial institutions (IFIs) for assistance on growth, investment climate, human capital, institutions/governance, and conflict and violence prevention. As the global economy evolves, they are asking for more attention to sustainable infrastructure, technology, trade/connectivity (both broad-based and in clusters and growth corridors) and inclusion (gender/small and medium sized-enterprises/urban and rural), and for help in the face of global shocks and global public "bads" such as communicable disease and climate change mitigation. 
For the most part, MDBs share similar approaches in the way they respond to client requests for assistance. However, there are three categories of clients where MDBs and their shareholders are divided on diagnosis and implementation - fragile contexts, highly indebted countries, and UMICs. As we discuss below, bridging these divides is essential for the system to operate effectively.

\section{Section 2. Enhancing MDB Coherence and Collaboration}

\section{Changing How MDBs Work Together}

The Rome Declaration of 2003 on harmonizing donor practices for aid delivery recognized that effective and efficient development support required increased coordination of the policies and procedures of donors "for preparing, delivering, and monitoring development assistance." Coupled with a "country-based approach that emphasizes country ownership and government leadership," the new approach to development envisaged a more coherent approach by the entire international community, unifying donor interventions with country strategies [OECD, 2003]. Over the past 14 years, through a series of conferences and declarations, the quest for operational coherence evolved to include civil society, parliamentarians, and the private sector. ${ }^{6}$ Repeatedly the world has pledged to "strengthen and use country systems, [and] improve harmonization by providers of development cooperation..." [OECD, 2012].

The rhetoric, however, has exceeded the reality of implementation. Sceptics have decried the results as mostly superficial bureaucracy with few tangible results and certainly not on the scale or depth hoped for in $2003 .^{7}$ One casualty has been budget support. Once heeded by donors, budget support has fallen over time in absolute and relative terms, partly because of the difficulty of reconciling it with results and accountability metrics. ${ }^{8}$

Despite these difficulties, client developing countries and bilateral donors alike continue to look to the MDBs to lead on the use of country systems in prioritization, allocation, and evaluation. They view MDBs as providing a needed antidote to the realization that bilateral donors' agendas are becoming increasing domestically driven.

MDBs have also sought to improve coherence and strengthen collaboration across their own activities. One particularly important but difficult area has been safeguards on projects. The perception has been that the World Bank has had the most rigorous specification of safeguards. Yet clients often see these as too burdensome and costly. After multiple attempts at simplification and emphasis on country systems, the right balance remains elusive. ${ }^{9}$ In setting up its safeguard policies, the Asian Infrastructure Investment Bank has tried to take on board lessons from the experience of other MDBs to ensure clear objectives to maintain standards, but without being overly rigid. The experience across the MDBs suggests that coherence requires striking the right balance between conformity and contestability.

Over the years, the areas of collaboration among MDBs have expanded greatly to cover evaluation, procurement systems, sectoral policies, financial policies, and knowledge platforms such as public private partnership (PPP) frameworks. More recently, there has been stepped up

${ }^{6}$ The Paris Agenda for Aid Effectiveness (2005), the Accra Agenda for Action (2008), the Busan Partnership for Effective Development Cooperation (2011) and the subsequent establishment of the Global Partnership for Effective Development Cooperation (2012), which sponsored high-level meetings in 2014 and 2016, the latter producing the Nairobi Document.

${ }^{7}$ See for example: [Brown, 2016].

${ }^{8}$ See for example: [Koch, Molenaers, 2015].

${ }^{9}$ See for example the discussion on pp. 19-21 and the dissent on pp. 27-28 in [Ahluwalia et al., 2016]. 
collaboration on climate, infrastructure, balance sheet optimization, and principles for provision of finance, all with the involvement of the G-20.

However, competition persists among MDBs on policy advice, pricing and financing modalities; it is sometimes healthy in expanding choices for clients, but sometimes creates problems for the overall functioning of the system. For example, some MDBs worry that access to policy-based funding from one MDB can reduce client demand for project loans from another MDB. As another example, some MDBs provide free technical assistance, while others struggle to create market-based fee-for-service programs. There are few guardrails for resolving these kinds of differences.

At the country level, technical assistance/cooperation is already a core activity for the MDBs, and it is likely to become even more valuable as countries grapple with new partners, particularly from the private sector. Government clients are increasingly demanding that MDBs provide skills in finance, project preparation, and evaluation that have been undeveloped until very recently. With country systems as the common denominator, closer collaboration of the MDBs in delivering technical assistance will reduce system-wide costs and help countries build capacity.

The SDGs call for a major ramping up in the scale and quality of investments, especially in sustainable infrastructure and human development at the country level. This in turn will require policy and institutional strengthening across all groups of countries, platforms for project preparation and delivery that can help both scale up and enhance the quality of projects and programs, and financing structures that can mobilize financing from all sources.

The largest and most complex need pertains to infrastructure. The absolute scale of investments required in the coming two decades, and the inherent complexities of infrastructure investment (the long-term nature, interconnectedness, social impacts, and externalities, positive and negative) make progress in the sector especially challenging. Infrastructure investments require robust policy and institutional settings as well as strong governance. In addition, project preparation requirements and the need for financing structures that can mobilize different pools of finance over the different phases of the project cycle add further layers of complexity. All of these tasks must be undertaken to manage and reduce risks and bring down the cost of capital.

MDBs are uniquely positioned to help tackle these constraints but need to step up their collaborative efforts in the following areas:

(a) joint efforts on diagnostic work and improving data; (b) platforms for project preparation and application of common standards and benchmarks for sustainable infrastructure; (c) knowledge platforms and tools for strengthening policy and institutional foundations and provision of technical assistance; and (d) cooperation on establishment of financing structures that can unlock investments at scale.

Joint efforts are underway to improve coordination on sustainable infrastructure across MDBs and with other stakeholders. One concrete outcome of this collaboration is SOURCE, a new platform to develop sustainable infrastructure across MDBs. Jointly developed by the MDBs and the private sector, SOURCE comprises a set of tools that "provides support to national and subnational governments and public agencies in improving infrastructure project bankability, quality and delivery, in increasing investment and crowding-in private finance, in strengthening their technical capacities and abilities to manage risks." ${ }^{10}$ When coupled with country-oriented platforms, like Colombia's Financiera de Desarrollo Nacional, scaled up results are possible. This represents best practice in MDB collaboration and coherence, and could

10 "About Source" Sustainable Infrastructure Foundation. Available at: https://public.sif-source.org/ about/about- source/ (accessed 25.05.2018). 
be extended to other sectors and become a model for large investment programming with private participation.

There is also tremendous scope for tapping the skills and institutional capacities across the MDBs. MDBs have developed key areas of specialization and experience that are of relevance to, and can be shared with, others. Examples include the pioneering work of the InterAmerican Development Bank Group on migration and remittances, violence prevention, and conditional cash transfers; the work of the European Bank for Reconstruction and Development Bank (EBRD) on capital market development and private sector energy efficiency; Asian Development Bank (AsDB) support to sub-regional projects, such as the Greater Mekong Subregional project, and; the World Bank's work on countries in fragile situations.

Yet, there are only a few examples where MDBs have worked together and taken advantage of the capabilities in sister institutions. More commonly, they operate independently. For example, each MDB has its own research department and independent evaluation office. They each develop individual country strategies. They have their own assessment frameworks for development effectiveness.

We recommend that MDBs define a common program of research, knowledge generation and good practices. They should undertake joint country and sector strategies, and apply common frameworks for effectiveness and impact, including goals and metrics. In particular, we advocate for joint knowledge work wherever there is a sectoral platform of the client country that needs support.

This is not to say that policy and operational coordination and coherence are always welcomed. Client countries search for policy options, not policy prescriptions, and have concerns that international financial institution (IFI) coordination could become monopolistic - a significant danger, given that history has shown that IFI policy prescriptions are not infallible. What clients do desire is policy coherence, meaning consistency of approaches across different levels of government and across sectors. Policy coherence points to a desire to manage, rather than ignore, trade-offs (for example, public investment strategies and debt sustainability) and exploit synergies across sectors (for example, sanitation and nutrition).

MDBs are increasingly looking for ways to bring private sources of finance into development financing. This is perhaps best exemplified by the cascade approach of the WBG, which seeks to link "reform, investment, mobilization, and catalyzation" by evaluating first whether a project can be financed by the private sector. If not, the cascade template then asks whether reforms be made to address market failures or whether risk mitigation measures can be used to induce private participation. Only in the latter instance would public and/or concessional finance be offered. ${ }^{11}$ While most other MDBs have similar objectives for mobilizing private finance, what is lacking are system-wide procedures that channel financing through national platforms. These common protocols could prevent "shopping" by the private sector for the best deal and limit counter-productive inter-MDB competition.

While MDBs have an array of instruments, including guarantees that should permit considerable mobilization of private capital, results to date have been disappointing. The OECD, in its survey of all aid agencies, bilateral and multilateral, found only $\$ 80$ billion over four years, mostly using guarantees and mostly in MICs [OECD, 2017].

A platform approach allows the pooling of all sources of long-term development finance, with concessional funds applied where appropriate to fill key gaps. For example, the approach could work for project preparation, technical assistance, or to compensate for environmental or social externalities. Significant potential for developing and tapping into local currency long-term financing now exists in selected countries. This line of thinking also links to policy

${ }^{11}$ See pages 5-6 of [World Bank, 2017]. 
coherence: local capital market development may be just as important as a specific project in supporting sustainable infrastructure.

The impediment appears to be the business and financing model for MDBs. Guarantees require the same amount of capital set-asides as loans, but are more complex to originate. [Humphrey, Prizzon, 2014]. In addition, loans are the main source of income for MDBs; loan margins fund the administrative staff costs needed to work on reforms to improve the enabling environment for private sector investments. As such, staff incentives are often based on loan mobilization.

In a platform approach, the business model of MDBs could change. Their comparative advantage in a world awash in liquidity is to provide initial funds and expertise for origination and upstream policy and institutional work; patient capital to take on construction and other risks from early-gestation activities; and affordable capital to help clients internalize social and environmental externalities.

Embracing a platform approach, unbundling these different services to the platform, and developing appropriate business models for each could permit MDBs to use their capital more effectively, including through asset sales programs that could allow for more rapid turnover of loans.

To free up more capital for development purposes, MDBs could also develop financing "exit mechanisms" to turn over their capital more rapidly for greater development impact. In such schemes, private sector investors with an appetite for developing country investments could purchase mature financial assets from MDBs, freeing their capital. While MDBs already have asset sales programs, getting such mechanisms to function at scale would require a significant change in pricing and business models.

\section{Developing a Shared Understanding of Approaches Among Different Clients}

MDBs face sharp challenges with respect to three types of clients. "Fragile" and conflict/ violence (FCV) affected states that are lagging behind and not converging with advanced economies (the International Monetary Fund (IMF) identifies 43 such countries in the latest World Economic Outlook database) [IMF, 2017]. These countries and states are the locus of the greatest concentration of poverty, yet also places where development efforts have been least effective [World Bank, 2014]. Heavily indebted countries, as classified by debt sustainability analyses, strive to balance the need for debt financing to accelerate growth with the desire to avoid debt crises. UMICs, with access to private capital markets, still ask for support in selected areas (often institutional and governance strengthening, sub-national development, or sustainable infrastructure with global spillovers), but are being graduated to conserve MDB capital in the short run.

\section{Fragile Contexts}

The New Deal for engagement in fragile states signed in 2011 and the World Development Report 2011 on Conflict, Security and Development reflect long-standing efforts to broaden support for post-conflict recovery by moving away from traditional aid efforts and financing of social services and infrastructure toward a focus on political settlement, security, justice and jobs. This agenda has increased urgency: The locus of global poverty will overwhelmingly be in fragile, mainly LIC and African states by 2025 [Kharas, Rogerson, 2017].

MDBs are well placed to support FCV affected countries, where these have legitimate governments. The reasons for this are fourfold: ${ }^{12}$

- First, MDBs have the finance, depth of expertise and scope that can support full- scale comprehensive approaches.

\footnotetext{
${ }^{12}$ This section draws on [McKechnie, 2016].
} 
- Second, by pooling funds, MDBs can avoid providing the fragmented assistance that overloads countries with weak institutions.

- Third, MDBs can pool and manage risks for bilateral donors and private capital, mitigating them through policy reform and sharing them through deployment of guarantees. FCV countries are some of the riskiest places to do any kind of business.

- Fourth, MDBs can take the long-term perspective that is necessary in fragile situations; building effective institutions can take 20-40 years [World Bank, 2011].

MDBs have an institutional legacy in financing infrastructure, where projects can take a decade from concept to results, and where governance arrangements can be structured to insulate their management from short-term political pressures.

To support reconstruction and institution building in FCV, we would recommend MDB shareholders and management tolerate variation in constitutional arrangements and economic policies and avoid influence over electoral processes. MDBs should do this while enabling greater multilateral engagement in strengthening accountable police and judiciary with a mind to safeguarding human rights, encouraging disarmament of irregular forces, advancing security sector reforms, and enhancing oversight by legislatures” [IEG, 2014].

Rules governing MDBs forbid interference in the political affairs of member countries; their articles also require impartial decisions based only on economic or social development considerations. Some interpretations of these articles impede MDBs in assisting countries to overcome some dimensions of fragility, leaving clients vulnerable to reversals in development progress.

A second recommendation would be to revise approaches to the country-based lending model in the case of FCV countries to allow a more creative use of MDBs' grant instruments. For example, grants would make it easier to fund both national and regional projects that reduce FCV. While countrybased lending has served central governments well, it is ill suited to financing sub-national governments, civil society or businesses. Nor does the country-based model lend itself to activities that span two or more countries, nor to settings where the government lacks legitimacy.

Third, we recommend $M D B$ shareholders adjust their oversight of $M D B$ operations in FCV countries. The two MDBs most active in fragile context - the World Bank and AfDB - have been criticised for their cumbersome fiduciary systems, which can be alien to a borrowing country's financial management, audit and procurement systems. Inflexible administrative procedures are another Achilles heel. Oversight by the boards should give greater attention to implementation and speed of results, rather than loan approvals. They could also ensure that MDBs are fit for the challenge of fragility, especially through adjusting their policies and procedures for greater agility in FCV contexts, decentralising highly qualified, empowered staff to country offices, using country systems wherever possible, and providing hands-on support to counterparts in low-capacity countries [McKechnie, 2016].

\section{High Debt Countries}

In the wake of the 2008 economic downturn and financial crisis, public debt sustainability in advanced economies was at the top of the international agenda. Meanwhile, external debt in developing countries was on the verge of falling off development practitioners and analysts' radar screens. This made sense, because debt ratios plummeted as the result of the debt relief initiatives in the 1990s and 2000s and the sustained economic growth in most of beneficiary countries. ${ }^{13}$

${ }^{13}$ From an average of 131 percent of gross national income (GNI) in 2000 across HIPCs to 35 percent in 2015 [Mustapha, Prizzon, forthcoming]. 
This positive picture is rapidly changing though. ${ }^{14}$ The risk is still high or moderate for 30 post-completion point heavily indebted poor countries (HIPCs) who benefited from multilateral debt relief (out of 36); two other HIPC post-completion point countries are in debt distress. The share of concessional financing declined in the majority of HIPC countries from 2005-2007 up to $2013-2015 .{ }^{15}$ Some countries are about to exceed debt limits set in their public financial management laws.

Scaling up resources from "billions to trillions" will largely entail resources that generate liabilities, rather than being grant financed. Most of the new, envisaged liabilities associated with blended finance projects are from the private sector at far less favorable terms and conditions than MDB lending. The mechanism for managing debt workouts in the future, including for multilateral debts, should be debated and clarified.

The increasing complexity of financing options requires a new skill set for debt sustainability assessments by the IFIs. They must understand rollover risk, contingent risks, and setasides for explicit and implicit guarantees, link debt management and fiscal policies, and better appreciate the quality and effectiveness of public investments. ${ }^{16}$

At the same time, no debt workout mechanisms exist when liabilities need restructuring. Multilateral debt mechanisms such HIPC or the Multilateral Debt Relief Initiative (MDRI) or the Paris Club may not suffice if another debt crisis occurs, as most debt comes now from private sources.

We recommend MDBs jointly prioritize and strengthen debt management capacity in borrowing countries. They should also review how the quality of public investment, policy reform track record, and availability and use of policy space affect debt sustainability assessments. Finally, they should develop principles and procedures for debt restructuring that reflect the increasingly complex nature of the creditor community.

\section{Graduation and the UMIC Support Issue}

Shareholders disagree on the role of the MDB system in UMICs. Some argue that any financial support to these countries should be sharply circumscribed (or even cut to zero except in exceptional circumstances), regardless of the level of concessionality from the point of view of the lender. These shareholders view engagement in UMICs as a zero- sum game, and prefer to reallocate resources to other countries. Others argue the opposite - that engagement with UMICs is valuable for all other countries. They have put forward four reasons:

1. Profitability from UMIC clients can add to capital and reserves, raise the portfolio quality of MDB assets, and thereby improve their credit rating and support greater lending to others. ${ }^{17}$

2. Engagement permits direct learning from development implementation innovations introduced by UMICs.

3. UMICs are often important partners in implementing global and regional public goods (for example, climate and water), and in managing regional spillovers and crises. They also

${ }^{14}$ UNCTAD [2016] and Jubilee Debt Campaign (2016)'s analyses and media articles (Financial Times, 2017, see https://www.ft.com/content/de5fab92-0f27-11e7-a88c-50ba212dce4d) find that servicing debt obligations has become more expensive in several SSA countries.

${ }^{15}$ [Mustapha, Prizzon, forthcoming].

${ }^{16}$ For example, staff at the IMF recently advocated for a "big push" on development expenditures in lowincome countries on the grounds that debt sustainability concerns could skew public investment choices toward projects with short-term returns (roads) rather than projects with far higher, longer-term returns (education). Available at: https://blogs.imf.org/2017/11/09/roads-or-schools-a-critical-tradeoff/ (accessed 25.05.2018).

${ }^{17}$ In the longer-term, UMICs can be stewarded to become large donors or capital contributors to multilaterals. 
serve as growth poles for neighboring countries that need to be encouraged to adopt global standards and improve regional connectivity and networks.

4. National governments in UMICs often cannot engage directly with sub-national entities without weakening frameworks of fiscal decentralization, so turn to international support for lagging areas.

The typical case for UMIC graduation assumes that private capital markets can replace lending from publicly supported international institutions when countries reach a certain income threshold and enjoy reasonable capital market access. Whether this assumption holds today, however, is far from obvious. Current discussions on PPPs, especially in big-ticket areas such as sustainable infrastructure, suggest that public and private finance is often complementary, with each having its own role in the value chain and its own comparative advantage in bearing risks. In fact, given the different stages of policy, institutional and financial constraints facing different sectors within a given developing country, graduation may be better considered as a country-sector issue rather than a country-national income issue.

We believe that, in the medium to long term, there is a powerful argument for the MDB system to engage in all developing countries. The real discussion for shareholders should be on the criteria for engagement, and the need to demonstrate a clear developmental purpose for any intervention. The "cascade" principles provide a useful frame: test whether there is a real need for public financing (including as a contribution to a global externality), identify whether such needs could be obviated in future through policy and institutional strengthening, but engage where the development case is compelling.

\section{MDBs and the Provision of GPGs}

The role of MDBs in providing selected GPGs is also important, especially where implementation is country-focused. In this respect, MDBs serve as idea generators, as coordinators, and as financiers. Their governance structure and their lending to sovereign governments are not a natural fit with GPG provision: their principal comparative advantage is in supporting national actions that overlap with the development agenda. However, over the years, their role has evolved organically rather than through a deliberate move on the part of shareholders to enter into the GPG business. As a result, no coherent GPG engagement model exists for the MDB system. A system-wide approach that integrates national, regional and global actions based on comparative strengths and deploys cooperative platforms of action is needed. In addition, it would be worth considering grant resources to attract, guide, and nudge national governments and the private sector to invest in ways that help the global community resolve a host of unmet global challenges. In instances where broader projects have GPG components, modified support in the form of grants may be appropriate. MDBs could also explore restructuring the governance of GPG "funds" to reflect an appropriate governance structure, as opposed to a shareholder/donor driven decision model. ${ }^{18}$

\section{Section 3. Shareholder Alignment}

Shareholder alignment and outdated governance are at the heart of many of the limitations that the MDBs face, both individually and collectively. To be effective and legitimate, of the MDB system requires a shared vision and purpose across stakeholders; changes in governance arrangements that preserve the multilateralism (including the processes of leadership se-

\footnotetext{
${ }^{18}$ See for example the discussion in [Ahluwalia et al., 2016].
} 
lection); determination of shareholding and decision rules; and reform in corporate governance structures to enable MDBs to be more cost-effective and responsive to clients' needs.

Shareholders need to provide a vision for what they expect MDBs to deliver. They have encouraged older MDBs to refresh their mandates and they have established new MDBs to fill perceived gaps in the system over time, but shareholders have not systematically reviewed the MDB system since 1944.

In carrying out the new mandates dictated by the current context, shareholders agree that the MDB system should be lean and green, nimble and flexible. The system should innovate in the use of technology, safeguards, and in learning the language of partnerships and of the private sector. It should achieve results at scale. Nevertheless, beyond these generalities, there are sharp differences among shareholders that remain unaddressed under current governance arrangements. These concern: (i) setting specific goals for the system, outlining the degree of ambition, and ensuring coherence in the mandates of individual institutions; (ii) setting a vision for the mobilization and deployment of public finance through the MDB system; (iii) enabling MDBs to cooperate more effectively by guiding the division of labor and contestability of the system; and (iv) ensuring that governance evolves to provide legitimacy and trust of the system.

\section{Setting Goals, Agreeing on Degree of Ambition, and Ensuring Cohesion in Mandates}

Shareholders diverge on their long-term vision for the multilateral system. Some view the system as one that should systematically work itself out of a job, permitting countries to take on greater responsibility for their own development with full reliance on private global capital markets. Others view the multilateral system as a permanent expression of international solidarity and an important instrument for addressing those left behind in all countries. These are distinct but opposing visions for the long-term goals of the system that urgently need to be reconciled.

Related to this is mandate creep. Ad hoc mandates to address emerging problems, funded on a case-by-case basis, pose a different set of problems for the MDB system. While such a tasking by certain shareholders or interested parties may be appropriately responsive to short-term emergency challenges, over time it can dilute an institution's core mandate, erode managerial oversight, and lead to confusion as to where responsibility lies, if anywhere.

Shareholders need to set expectations for what the MDB system should deliver as contributions toward Agenda 2030, the mitigation of shocks, and the provision of global public goods. System-wide performance can then be regularly assessed against these expectations.

(These expectations need to be sufficiently granular to be effective - SMART targets. For example, the MDB joint report on climate finance sets out monitorable targets for climaterelated lending volumes, by institution; ${ }^{19}$ another example is the nascent MDB commitment to measure and report on the net carbon emissions of their operations)..$^{20}$

There should be a periodic inventory of ambition and mandates across the MDB system with decisions as to when "emerging challenges" merit a permanent effort, with corresponding increases in permanent resources untied to a particular shareholder or funding entity. Given the urgency for action in the upcoming two decades, shareholders also urgently need to assess whether progress on outcomes is rapid enough.

${ }^{19}$ See, for example, http://pubdocs.worldbank.org/en/266191504817671617/2016-joint-report-on-mdbsclimate-finance.pdf.

${ }^{20}$ See https://www.economist.com/news/finance-and-economics/21730448-environmentalists-allegetheir-lending-has-been-less-green. 


\section{Setting a Vision for the Mobilization and Deployment of Public Finance}

Shareholder resources, both for concessional and non-concessional on-lending, are not being deployed in the most effective way. The model of allocation according to country income levels no longer seems optimal. Consider this: shareholders argue for deploying concessional funds to the poorest countries, yet in many special situations, the actual association between recipient country per capita income and aid allocations is negligible, both for multilaterals and for bilateral funding. As another example: low-income countries have availed of private finance for revenue-generating infrastructure investments, when access to non-concessional multilateral resources could have been effective, with better development results because concessional funding could then be redeployed. Conversely, MICs sometimes need concessional funds, but current procedures make this cumbersome, as in the case of Lebanon and Jordan's efforts to help Syrian refugees.

Nevertheless, shareholders should take comfort in the fact that the existing MDB financing model is the most efficiently structured form of international public finance. Shareholders typically only pay-in 6 percent of total subscribed capital, so even with extremely conservative debt/equity ratios of 1:1, lending can be a 16-times multiple of contributions. ${ }^{21}$ If private sector and client government funds match or exceed multilateral lending, total investment projects of more than 32-times are possible. Over time, as MDBs reap profits from equity investments, leverage increases still further, making a 50-fold multiplier feasible over a decade. This arithmetic suggests that $\$ 40$ billion injected into the MDB system could generate $\$ 2$ trillion in project and program finance for sustainable development.

It is this potential for leverage and mobilization of development finance that makes the MDB system so attractive as an instrument for achieving the global community's goals.

Related to the question of capital adequacy is the issue of risk tolerance of shareholders and the likelihood of a call on unpaid, subscribed capital. Multilateral institutions are unique bodies, and methodologies for their credit rating are imperfect and evolving, with little hard empirical data points (no IFI has actually defaulted on its debt and preferred creditor status is hard to assess). Hence, some claim that IFIs are operating at a AAA+++ level and could take on substantially more risk without jeopardizing their rating, while others are concerned about maintaining the AAA rating at all costs, particularly for any individual IFI.

There have been many recommendations on MDB capital adequacy, the impact of callable capital, ${ }^{22}$ balance sheet optimization, credit risk concentration and pooling, and the like. We suggest that the deeper issue is to agree on and signal the scale of activity of MDBs (both financial and nonfinancial service delivery) and to work backward to develop scenarios for capital and risk tolerance. In our view, scaling the system to deliver trillions more in project and program finance over the next decade or so is an appropriate starting point for shareholder discussions and this would probably require allowing the institutions to operate with less restrictive financial ratios, while still maintaining their AAA rating.

${ }^{21}$ Total World Bank paid-in capital of $\$ 16.1$ billion supports subscribed capital of \$268.9 billion as of June 30, 2016. Available at: http://treasury.worldbank.org/cmd/htm/financial_shareholder.html (accessed 25.05.2018).

${ }^{22}$ Callable capital totals more than $\$ 650$ billion for the World Bank and the four major regional MDBs, but the vast majority is from countries with less than AAA ratings and of little use to MDBs, according to rating agency methodologies. To make better use of callable capital, MDB shareholders and their legislatures should more clearly define the circumstances and process by which callable capital can be called, which might convince rating agencies to give it more credit in their capital adequacy calculations [Humphrey, 2017, op. cit.] 


\section{Enabling MDBs to Cooperate More Effectively Among Themselves}

Major shareholders have long taken different views of individual institutions within the MDB system. The report of the Meltzer Commission, established by the U.S. Congress in 1998, was blunt in its assessment of why the U.S. Treasury seemed to favor the expansion of the World Bank over that of regional development banks: "The U.S. Treasury does not wish to see power and responsibility shift to the countries in the region. I [Meltzer] believe a shift of this kind is likely in coming years, and it is best to make the transfer in an orderly way. Indeed, in Europe and Asia the movement toward greater regional control is well underway" [Meltzer, 2004].

If MDBs are to cooperate more effectively as a system, shareholders must provide each institution with additional flexibility to move beyond its geographic mandate if such a move can add value to the system as a whole.

Given different client bases and charters, subject matter expertise among MDBs has evolved organically rather than through top-down mandates. At times, such expertise emerged from research and operational engagements with repeat clients. As examples, EBRD has welldeveloped skills and experience on the complexities of private sector financing, evaluation and managing risk, especially in the energy sector; IDB is collaborating with universities; AsDB has done extensive research and operations on regional spatial data and infrastructure; AfDB on rural water; IBRD on climate.

Yet there are few cases of system-wide efforts to tap such expertise, either in formal partnerships or through inter-MDB memoranda of understanding. Best practice, such as EBRD/ AfDB collaboration on private sector development in North Africa, could be better shared and practiced, and geography should not become a barrier to the use of specialized skills across the MDB system [African Development Bank, 2011].

We believe that, with modern communications technology, subject matter specialization should be used across the globe. Formal mechanisms to share best practice should be strengthened and allowing sister institutions to take the lead in particular areas would permit the system to realize economies of scale and scope in providing services. Helping countries craft coherent technical assistance strategies is one area in which specialized MDBs could be of considerable use.

In examining the distribution of specializations in a systemic manner, the significant presence of U.N. agencies in many domains must be reckoned with; MDB shareholders need to be wary of undercutting or duplicating other international efforts to achieve the SDGs through the propagation of competing mandates.

\section{Ensuring Governance Evolves to Support Legitimacy and Effectiveness}

Client trust is central to the MDB value proposition and is based on client confidence with current and future governance. The Zedillo Commission views on the World Bank are worth repeating:

"Current mechanisms for strategy formulation are not adequate for setting priorities and guiding operations. As a result, they undermine members' ownership of the Group's strategy, foster mission creep, and increase the risk of misallocating resources or stretching them too thin. In addition, the institution's decision-making process is widely seen as allowing many member countries insufficient voice and opportunities for participation. Finally, there is insufficient institutional accountability for results - a problem that ultimately weakens the effectiveness and legitimacy of the World Bank" [Zedillo, 2009].

These observations are as relevant to the MDB system as to individual institutions. A vision of a system serving all developing countries requires a governance structure that permits adequate voice. 
Governance in multilateral institutions does matter. Research suggests that among MDBs, those where borrowing countries have more voice have: less reliance on a compliance rulesbased culture, and more cost-effective linkage between safeguards and development benefits; less conservative financial policies; more flexibility in allocation procedures; and less internal oversight and cost [Kharas, 2015].

The corporate governance of the MDBs should guide management choices on strategy, flexibility and responsiveness, while holding them accountable for development results. In some MDBs, however, the number of staff in shareholder offices has swelled to levels (several hundred in the case of IBRD) that are inconsistent with simple provision of strategic oversight. Today's Board members are like parliamentarians who impose substantial costs on the system with few benefits in terms of transparency and accountability of management.

If the MDBs are to behave as a global system, the governance of each part should permit a global representation. What is at stake is the preservation of the cooperative nature of the institutions as representing the collective response of nations to the pressing global development issues of the day.

To realize a holistically functioning MDB system, strategy setting for the long-term, and accountability for results, are urgently needed. The MDBs have made a start in thinking through collective commitments, as evinced in the "Joint MDB Statement of Ambitions for Crowding in Private Finance." Taking a page from that joint effort, the MDBs could use the same kind of methodology to identify their contributions to Agenda 2030 results. A governance framework that periodically takes stock of system - wide results, say every four or five years, would facilitate follow-up and course corrections in individual institutions. ${ }^{23}$ Likewise, the time is ripe for a careful system-wide review of the costs and benefits of current Board structures and staffing.

No formal structure that would facilitate an exchange of views and the forging among shareholders of a consensus on the mandate and operational modalities for the MDB system exists. Rather than construct a new layer, we recommend making use of existing fora.

Any dialogue on the MDB system must be legitimate and effective and enjoy the trust of all MDB stakeholders. It is likely that multiple fora might be needed. For example, a special session of the Development Committee could be organized; but representation there is the 25 members represented on the boards of executive directors of the World Bank and the IMF. Pursuing the discussion at the U.N., perhaps in conjunction with the quadrennial High Level Political Forum Summit, would add legitimacy and broaden representation. Bringing recommendations to the G-20 offers the chance to engage more directly with ministers of finance. Each forum has its own added value; together they could show a way forward for the system as a whole.

\section{Section 4. Summary and Conclusions}

Government and market failures are rife in developing countries, and addressing them in a way that advances sustainable development and achieves the goals of Agenda 2030 remains key to the fundamental mandate of MDBs. In a world with new opportunities provided by data, technology, innovation and a new willingness of private capital to invest in developing countries, the scope for MDBs to scale up their development impact is considerable. There is also an urgency to do so now, as today's choices regarding the scale and technology of investments in infrastructure and human capital will lock-in development pathways for decades to come.

While MDBs' considerable financial, human and cultural assets can help clients, teamwork among the multilaterals is rarely encouraged. The geographic boundaries that have shaped

${ }^{23}$ See for example the discussion on pp. 26-26 in [Ahluwalia et al., op. cit]. 
the development finance architecture are blurring. While geography will remain an important element of comparative advantage for regional banks, they each have expertise that can be more widely used by the system.

The greatest risk today is of "active inertia." Independent evaluations suggest the MDBs are each successful in their own activities, but are not collectively delivering at the scale and scope demanded of them, nor investing enough in systems, such as those for common environmental, social and governance standards, which would facilitate inter- operability. In such an environment, incremental governance reviews within each institution will not generate the big and bold changes to the system that are needed.

Such changes include potentially fundamental shifts in business models to focus more on upstream activities - from project and program design through construction and implementation.

Another way to correct inertia is for the MDBs to focus on institutional support to develop national platforms that serve as tools for planning and originating projects and that can pool different sources of finance, including long-term local currency capital.

Other business model changes should revolve around engagements in contexts of fragility, high debt, and UMIC - levels of prosperity.

Changes in financial models are needed as well. Discipline in optimizing the use of capital could require greater levels of asset sales and the recycling of funds. This in turn raises questions of loan pricing. It could also imply greater use of risk-sharing and risk- mitigation instruments that need appropriate pricing.

Internal staff incentives also need review to align with new metrics of knowledge, de-risking, mobilization of private finance and institutional collaboration.

The responsibility for introducing these changes falls to the governance of each MDB. Currently, board involvement in each transaction in most MDBs distracts attention from efforts to improve efficiency, effectiveness and legitimacy in each institution. Change in each of these areas could yield substantial benefits.

We are concerned that an incremental shareholder review process among MDBs will not generate the kind of governance improvements the entire system needs. Accordingly, we propose more structured discussions on the MDBs in three fora: the Development Committee, the U.N.'s quadrennial High Level Political Forum Summit on the SDGs, and the G-20. These discussions could take stock of whether the impact of the MDB system is delivering sufficiently, in scope and breadth, on the major challenges faced in implementing the world's global goals.

\section{References}

Ahluwalia M.S., Summers L., Velasco A., Birdsall N., Morris S. (2016) Multilateral Development Banking for This Century's Development Challenges. Five Recommendations to Shareholders of the Old and New Multilateral Development Banks Project Directors. Available at: https:/www.cgdev.org/sites/default/files/ multilateral-development-banking-report-five-recommendations.pdf (accessed 25.05.2018).

African Development Bank (2011) Memorandum of Understanding between European Bank for Reconstruction and Development and the African Development Bank and the African Development Fund. 10 September. Available at: https://www.afdb.org/fileadmin/uploads/afdb/Documents/Legal-Documents/signed\%20 memorandum $\% 20$ of $\% 20$ understanding $\% 20$ between $\% 20$ ebrd $\% 20$ and $\% 20 \mathrm{adb} \% 20$ and $\% 20$ adf.pdf (accessed 25.05.2018).

Bhattacharya et al. (2016) Delivering on Sustainable Infrastructure for Better Development and Better Climate. Brookings/LSE/NCE. Available at: https://www.brookings.edu/research/delivering-on-sustainableinfrastructure-for-better-development-and-better-climate/ (accessed 25.05.2018). 
Brown S. (2016) Putting Paris into Practice: Foreign Aid, National Ownership, and Donor Alignment in Mali and Ghana. WIDER Working Paper 2016/145, December 2016.

Gurria J.A., Volker P. (2001) The Role of the Multilateral Development Banks in Emerging Economies. The Carnegie Endowment for International Peace.

Humphrey C., Prizzon A. (2014). Guarantees for Development. A Review of Multilateral Development Bank Operations. Available at: https://www.odi.org/publications/9130-guarantees-development-review-multilateral-development-bank-operations (accessed 25.05.2018).

Humphrey C. (2017) Six Proposals to Strengthen the Finances of Multilateral Development Banks. ODI Working and Discussion Paper, April. Available at: https://www.odi.org/sites/odi.org.uk/files/resource-documents/11451.pdf (accessed 25.05.2018).

IEG (2014) World Bank Group Assistance to Low-Income Fragile and Conflict-Affected States: An Independent Evaluation, p. xiii. Available at: https://openknowledge.worldbank.org/handle/10986/16999 (accessed 25.05.2018).

IMF (2017) World Economic Outlook Database, October. Available at: https://www.imf.org/external/pubs/ft/ weo/2017/02/weodata/index.aspx (accessed 25.05.2018).

Kharas H. (2015) The Post-2015 Agenda and the Evolution of the World Bank Group. The Brookings Institution, GED Working Paper 92, September. Available at: https://www.brookings.edu/wp- content/uploads/2016/07/Kharas-WBG-evolution-and-post2015-agenda-2.pdf (accessed 25.05.2018).

Kharas H., Rogerson A. (2017) Global Development Trends and Challenges: Horizon 2025 Revisited, ODI Research Reports and Studies, October. Available at: https://www.odi.org/publications/10940-global-development-trends-and-challenges-horizon-2025-revisited (accessed 25.05.2018).

Koch S., Molenaers N. (2015) The Europeanisation of Budget Support: Do Government Capacity and Autonomy Matter? European Politics and Society, vol. 17, no 1, pp. 90-104.

OECD (2017) Amounts Mobilized from the Private Sector by Official Development Finance Interventions. Available at: https://www.oecd.org/dac/financing-sustainable-development/development-finance-data/Preliminary- results-mobilisation.pdf (accessed 25.05.2017).

OECD (2012) The Busan Partnership for Effective Development Cooperation. Available at: http://www.oecd. org/development/effectiveness/busanpartnership.htm (accessed 25.05.2018).

OECD (2003) The Rome Declaration. Available at: https://www.oecd.org/dac/effectiveness/31451637.pdf (accessed 25.05.2018).

McKechnie A. (2016) Fragility, Conflict and Violence as Global Public Goods: Strengthening Engagement by Multilateral Development Banks. ODI Research Report, October.

Meltzer A.H. (2004) The Report of the International Financial Institution Advisory Commission: Comments on the Critics. The IMF and its Critics: Reform of Global Financial Architecture (D. Vines, L. Christopher (eds)). Cambridge: Cambridge University Press, pp. 106-123.

Mustapha S., Prizzon A. (forthcoming) Taking Stock of Debt Relief Initiatives 20 Years on and What the New Development Finance Landscape Means for External Public Debt Sustainability. ODI.

UNCTAD (2016) The Economic Development in Africa Report 2016: Debt Dynamics and Development Finance in Africa. Available at unctad.org/en/PublicationsLibrary/aldcafrica2016_en.pdf (accessed 25.05.2018).

World Bank (2011) World Development Report 2011: Conflict, security and development. Washington DC: World Bank. Available at: https://openknowledge.worldbank.org/handle/10986/4389 (accessed 25.05.2018).

World Bank. Group (2014) World Bank Group Assistance to Low-Income Fragile and Conflict-Affected States: An Independent Evaluation. Available at: https://openknowledge.worldbank.org/handle/10986/16999 (accessed 25.05.2018).

World Bank (2017) Forward Look, A Vision for the World Bank Group in 2030 - Progress and Challenges, March. Available at: http://siteresources.worldbank.org/DEVCOMMINT/Documentation/23745169/ DC2017-0002.pdf (accessed 25.05.2018).

Zedillo E. (2009) Repowering the World Bank for the 21st Century. Available at: http://siteresources.worldbank.org/news/Resources/wbgovernancecommissionreport.pdf (accessed 25.05.2018). 


\title{
Новая глобальная повестка и будущее многосторонних банков развития ${ }^{1}$
}

\author{
А. Бхаттачария, Х. Харас, М. Плант, А. Приццон
}

Бхаттачария Амар - старший сотрудник программы по мировой экономике и глобальному развитию Института Брукингса; USA, Washington, DC 20036, 1775 Massachusetts Ave., NW; E-mail: communications@ brookings.edu

Харас Хоми - исполняющий обязанности вице-президента и директор программы по мировой экономике и глобальному развитию Института Брукингса; USA, Washington, DC 20036, 1775 Massachusetts Ave.; E-mail: hkharas@brookings.edu

Плант Марк - директор направления финансирования развития и старший сотрудник Центра глобального развития; USA, Washington DC 20036, 2055 L Street NW; E-mail: mplant@cgdev.org

Приццон Аннализа - старший научный сотрудник Института зарубежного развития; UK, London SE1 8NJ, 203 Blackfriars Road; E-mail: a.prizzon@odi.org.uk

Новая глобальная повестка дня, ядром которой является Повестка дня в области устойчивого развития на период до 2030 г., всеобъемлюща и универсальна. В настоящее время определены три главные цели: возобновление роста, обеспечение реализации Целей устойчивого развития (ЦУР) и выполнение задач Парижского соглашения по климату, связанных с борьбой с изменением климата и адаптацией к его последствиям. Достижение этих целей потребует значительного расширения и переориентации инвестиций, особенно в области устойчивой инфраструктуры и человеческого развития. Их реализация является неотложной задачей, поскольку мир столкнулся с самой большой волной экспансии городов в истории, а в течение следующих 15 лет начнет функционировать больше инфраструктурных объектов, чем существует в мире сегодня. Также это последняя возможность выработки эффективных подходов к управлению масштабными демографическими переходами.

Капитальные вложения и технологический выбор в ближайшие два десятилетия закрепят тенденции карбонизации, урбанизации и демографии. Они будут определять будущее человечества и нашей планеты до конца нынешнего столетия и далее.

${ }^{1}$ Институт Брукингса - некоммерческая организация, проводящая исследования и осуществляющая выработку независимых политических решений. Миссия института - проводить высококачественные независимые исследования и на основе этих исследований предоставлять инновационные практические рекомендации для разработчиков политики и общественности.

Институт зарубежного развития является ведущим независимым аналитическим центром по вопросам международного развития и гуманитарной деятельности. Его миссия состоит в стимулировании и информировании политики и практики, направленных на сокращение масштабов нищеты и обеспечение устойчивых средств к существованию в развивающихся странах за счет сочетания высококачественных прикладных исследований, практических консультаций по вопросам политики и ориентированного на эту политику обсуждения и распространения знаний.

Центр глобального развития работает над сокращением глобальной нищеты и неравенства посредством скрупулезных исследований и активного взаимодействия с политическим сообществом, чтобы сделать мир более процветающим, справедливым и безопасным для всех.

Выводы и рекомендации данной статьи принадлежат исключительно ее авторам и не отражают взглядов упомянутых учреждений, их руководства или других сотрудников.

Поддержка данной публикации была великодушно предоставлена Фондом Билла и Мелинды Гейтс и Фондом Рокфеллера. Институт Брукингса, Центр глобального развития и ODI считают, что основная ценность их работы заключается в абсолютной приверженности качеству, независимости и воздействию. Деятельность, поддерживаемая их спонсорами, отражает эту приверженность.

Более ранняя версия настоящей статьи была представлена на симпозиуме Группы видных деятелей «Группы двадцати» по глобальному финансовому управлению во Франкфурте, Германия, 4 декабря 2017 г. Данная версия статьи значительно улучшена по результатам обсуждения. 
Условия, в которых предстоит решать эти задачи, весьма сложны. Во многих странах рост инвестиций и производительности замедлился, усиливается неравенство и сохраняется безработица, растут напряженность, уязвимость к шокам и их частота. В то же время существуют масштабные возможности для использования новых технологий и растущего потенциала частного сектора. Сегодняшний сверхсвязанный мир требует сочетания мероприятий, охватывающих частные блага, национальные общественные блага и региональные / глобальные общественные блага для решения задач устойчивого развития.

Повестка дня требует достижения адекватных масштабов государственного вмешательства, серьезного отношения к социальной и экологической устойчивости, а также управления побочными эффектами, распространяемыми между секторами и через границы. Также требуется активизация международного сотрудничества для реализации трансформационных изменений и мобилизации финансирования в беспрецедентных маситабах.

Многосторонние банки развития (МБР), обладающие высокоэффективным потенциалом помощи странам в укреплении политических и институциональных основ реализации данных задач, а также привлечения финансирования, должны сыграть в этом процессе центральную роль. Они пытаются реагировать на существующий запрос, но людские и финансовые ограничения, а также неясные и чрезмерно широкие мандаты, определяемые акционерами, сдерживают их. Уточнение мандатов и устранение указанных ограничений имеют важное значение для расширения и повышения эффективности поддержки ими новой глобальной повестки дня.

Уникальная финансовая структура МБР позволяет им использовать ресурсы акционеров, мультиплицируя их и предоставляя финансирование по низкой стоимости. Это, в свою очередь, позволяет привлекать финансирование из других источников, особенно со стороны частного сектора. При лучшей системной координации МБР смогут повысить качество удовлетворения потребностей все более разнообразных клиентов, но для этого требуются консенсус среди акционеров и финансовая поддержска с их стороны соответствующих усилий МБР.

Независимые оценки показывают, что каждый отдельно взятый МБР демонстрирует хорошие результаты работы, но в рамках системы эффективность недостаточна.

В данной статье предлагаются пути улучшения согласованности политики и операционной деятельности между МБР и описывается, как совершенствование управления со стороны акционеров может способствовать достижению этой цели. Основное внимание уделяется необходимости увеличения финансирования инвестиций в развивающихся странах, но статья должна рассматриваться в более широком контексте управления процессами глобализации, особенно в отношении торговли и финансовой стабильности.

Ключевые слова: многосторонние банки развития; цели устойчивого развития; инвестиции; развитие человеческого потенциала; глобальное управление

Для цитирования: Бхаттачария А., Харас Х., Плант М., Приццон А. (2018) Новая глобальная повестка и будущее многосторонних банков развития // Вестник международных организаций. Т. 13. № 2. С. 101-124. DOI: 10.17323/1996-7845-2018-02-06.

Текст «Новая глобальная повестка и будущее многосторонних банков развития» А. Бхаттачарии, X. Хараса, М. Планта, А. Приццон переведен и опубликован с разрешения Института Брукингса (Тһе Brookings Institution), Института зарубежного развития (ODI) и Центра глобального развития (CGD) ${ }^{2}$.

(c) Brookings, ODI \& CGD. Институт Брукингса (The Brookings Institution), Институт зарубежного развития (ODI) и Центр глобального развития (CGD) не несут ответственности за качество перевода.

\section{Источники}

Ahluwalia M.S., Summers L., Velasco A., Birdsall N., Morris S. (2016) Multilateral Development Banking for This Century's Development Challenges. Five Recommendations to Shareholders of the Old and New Multilateral Development Banks Project Directors. Режим доступа: https://www.cgdev.org/sites/default/files/ multilateral-development-banking-report-five-recommendations.pdf (дата обращения: 25.05.2018).

${ }^{2}$ Bhattacharya A., Kharas H., Plant M., Prizzon A. (2018) The New Global Agenda and the Future of the Multilateral Development Bank System. The Brookings Institution, Overseas Development Institute (ODI), the Center for Global Development (CGD). February 2018. Режим доступа: https://www.brookings. edu/wp-content/uploads/2018/02/epg_paper_on_future_of_mdb_system_jan301.pdf. 
African Development Bank (2011) Memorandum of Understanding between European Bank for Reconstruction and Development and the African Development Bank and the African Development Fund. 10 September. Режим доступа: https://www.afdb.org/fileadmin/uploads/afdb/Documents/Legal-Documents/signed\%20 memorandum $\% 20$ of $\% 20$ understanding $\% 20 \mathrm{between} \% 20 \mathrm{ebrd} \% 20 \mathrm{and} \% 20 \mathrm{adb} \% 20 \mathrm{and} \% 20 \mathrm{adf}$.pdf (дата обращения: 25.05.2018).

Bhattacharya et al. (2016) Delivering on Sustainable Infrastructure for Better Development and Better Climate. Brookings/LSE/NCE. Режим доступа: https://www.brookings.edu/research/delivering-on-sustainable-infrastructure-for-better-development-and-better-climate/ (дата обращения: 25.05.2018).

Brown S. (2016) Putting Paris into Practice: Foreign Aid, National Ownership, and Donor Alignment in Mali and Ghana. WIDER Working Paper 2016/145. December.

Gurria J.A., Volker P. (2001) The Role of the Multilateral Development Banks in Emerging Economies. The Carnegie Endowment for International Peace.

Humphrey C., Prizzon A. (2014) Guarantees for Development. A Review of Multilateral Development Bank Operations. Режим доступа: https://www.odi.org/publications/9130-guarantees-development-review-multilateral-development-bank-operations (дата обращения: 25.05.2018).

Humphrey C. (2017) Six Proposals to Strengthen the Finances of Multilateral Development Banks. ODI Working and Discussion Paper. April. Режим доступа: https://www.odi.org/sites/odi.org.uk/files/resource-documents/11451.pdf (дата обращения: 25.05.2018).

IEG (2014) World Bank Group Assistance to Low-Income Fragile and Conflict-Affected States: An Independent Evaluation. Р. хіii. Режим доступа: https://openknowledge.worldbank.org/handle/10986/16999 (дата обращения: 25.05.2018).

IMF (2017) World Economic Outlook Database. October 2017. Режим доступа: https://www.imf.org/exter$\mathrm{nal} / \mathrm{pubs} / \mathrm{ft} /$ weo/2017/02/weodata/index.aspx (дата обращения: 25.05.2018).

Kharas H. (2015) The Post-2015 Agenda and the Evolution of the World Bank Group. The Brookings Institution, GED Working Paper 92, September 2015. Режим доступа: https://www.brookings.edu/wp- content/ uploads/2016/07/Kharas-WBG-evolution-and-post2015-agenda-2.pdf (дата обращения: 25.05.2018).

Kharas H., Rogerson A. (2017) Global Development Trends and Challenges: Horizon 2025 revisited, ODI Research Reports and Studies, October. Режим доступа: https://www.odi.org/publications/10940-globaldevelopment-trends-and-challenges-horizon-2025-revisited (дата обращения: 25.05.2018).

Koch S., Molenaers N. (2015) The Europeanisation of Budget Support: Do Government Capacity and Autonomy Matter? // European Politics and Society. Vol. 17. No. 1. P. 90-104.

OECD (2017) Amounts Mobilized from the Private Sector by Official Development Finance Interventions. Режим доступа: https://www.oecd.org/dac/financing-sustainable-development/development-finance-data/ Preliminary- results-mobilisation.pdf (дата обращения: 25.05.2017).

OECD (2012) The Busan Partnership for Effective Development Cooperation. Режим доступа: http://www. oecd.org/development/effectiveness/busanpartnership.htm (дата обращения: 25.05.2018).

OECD (2003) The Rome Declaration. Режим доступа: https://www.oecd.org/dac/effectiveness/31451637. pdf (дата обращения: 25.05.2018).

McKechnie A. (2016) Fragility, Conflict and Violence as Global Public Goods: Strengthening Engagement by Multilateral Development Banks. ODI Research Report. October.

Meltzer A.H. (2004) The Report of the International Financial Institution Advisory Commission: Comments on the Critics // The IMF and its Critics: Reform of Global Financial Architecture / D. Vines, L. Christopher (eds). Cambridge: Cambridge University Press. P. 106-123.

Mustapha S., Prizzon A. (forthcoming) Taking Stock of Debt Relief Initiatives 20 Years on and What the New Development Finance Landscape Means for External Public Debt Sustainability. ODI.

UNCTAD (2016) The Economic Development in Africa Report 2016: Debt Dynamics and Development Finance in Africa. Режим доступа: unctad.org/en/PublicationsLibrary/aldcafrica2016_en.pdf (дата обращения: 25.05.2018). 
World Bank (2011) World Development Report 2011: Conflict, Security and Development. Washington DC: World Bank. Режим доступа: https://openknowledge.worldbank.org/handle/10986/4389 (дата обращения: 25.05.2018).

World Bank. Group (2014) World Bank Group Assistance to Low-Income Fragile and Conflict-Affected States: An Independent Evaluation. Режим доступа: https://openknowledge.worldbank.org/handle/10986/16999 (дата обращения: 25.05.2018).

World Bank (2017) Forward Look, A Vision for the World Bank Group in 2030 - Progress and Challenges. March. Режим доступа: http://siteresources.worldbank.org/devcommint/Documentation/23745169/ DC2017-0002.pdf (дата обрашения: 25.05.2018).

Zedillo E. (2009) Repowering the World Bank for the 21st Century. Режим доступа: http://siteresources. worldbank.org/NEWS/Resources/WBGovernancecommissionreport.pdf (дата обращения: 25.05.2018). 